\title{
Evaluation of Coating Systems for Nonferrous Metal Surfaces
}

by Timothy D. Race

Both aluminum and galvanized steel are used on many Corps of Engineers projects. Civil Works Guide Specification CWGS-09940 specifies coatings for the protection of these nonferrous metal surfaces in various applications, but some of these coatings are no longer in compliance with current or anticipated government restrictions on volatile organic compound (VOC) content.

The U.S. Army Construction Engineering Research Laboratories (USACERL) was tasked to study select coating systems and identify alternative materials that can meet CWGS-09940 performance specifications while conforming to regulatory VOC content levels. Alternatives were to be sought from commercially available products or existing Federal Specification paints in order to conform with current Federal acquisition reform initiatives.

The performance of selected test and control coatings was evaluated on aluminum and galvanized steel surfaces in laboratory tests including fresh water immersion and accelerated cyclic corrosion exposures. Exposed test panels were evaluated for adhesion, blistering, delamination, undercutting at the scribe, and corrosion. The research identified several suitable commercially available alternative coatings for nonferrous metal surfaces used in various environmental exposures. Based on the results of this study, revisions of CWGS-09940 are recommended. 
SF 298 


\section{Foreword}

This study was conducted for the Directorate of Civil Works, Headquarters, U.S. Army Corps of Engineers, under Civil Works I nvestigations and Studies Work Unit 31205, "Devel oping High-Performance Coatings." Thetechnical monitor was J ohn Gilson, CECW-EE.

The work was performed by the Materials Science and Technology Division (FL-M) of the Facilities Technol ogy Laboratory (FL), U.S. Army Construction Engineering Research Laboratories (USACERL). The USACERL Principal Investigator was Timothy D. Race. Dr. Ilker R. Adiguzel is Acting Chief, CECER-FL-M, and Donald F. Fournier is Acting Operations Chief, CECER-FL.

COL J ames A. Walter is Commander of USACERL, and Dr. Michael J . O'Connor is Director. 


\section{Contents}

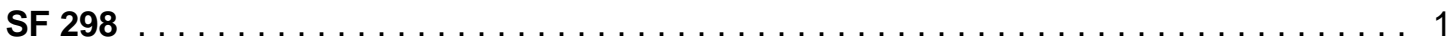

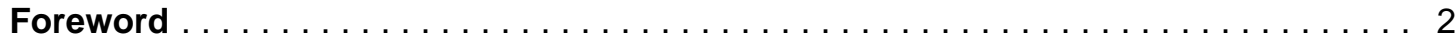

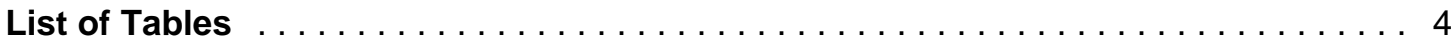

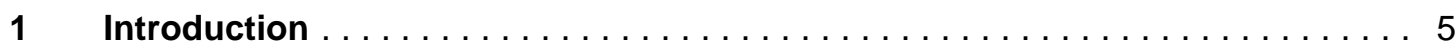

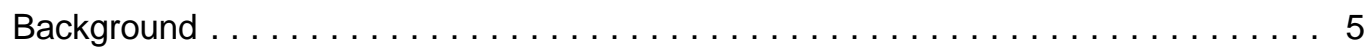

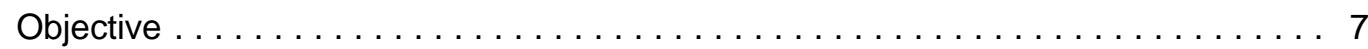

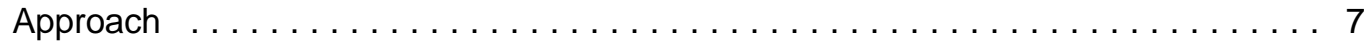

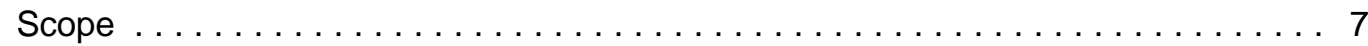

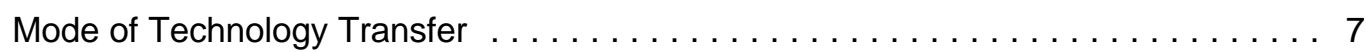

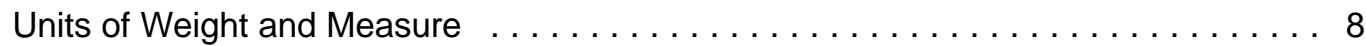

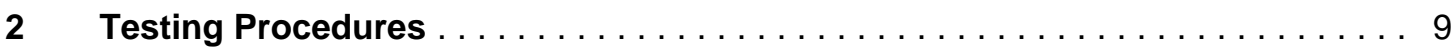

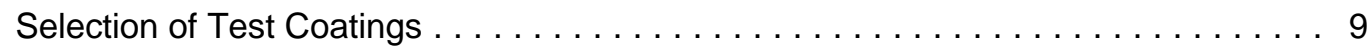

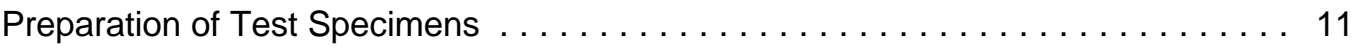

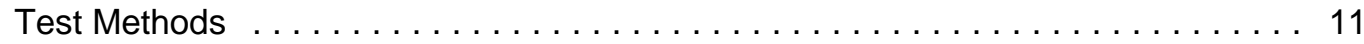

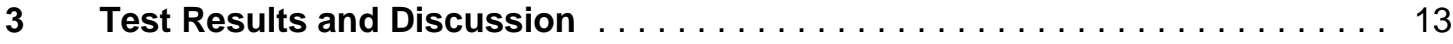

Performance of Coatings on Hot-Dip Galvanized Steel $\ldots \ldots \ldots \ldots \ldots \ldots$

Failure Mechanisms of Coatings on Galvanized Steel . . . . . . . . . . . . 17

Performance of Coatings on Aluminum $\ldots \ldots \ldots \ldots \ldots \ldots \ldots \ldots \ldots \ldots \ldots \ldots$

4 Conclusions and Recommendations $\ldots \ldots \ldots \ldots \ldots \ldots \ldots \ldots \ldots \ldots \ldots \ldots \ldots \ldots \ldots$

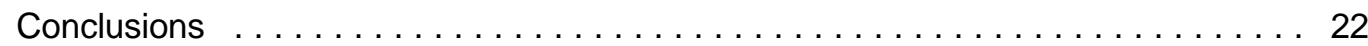

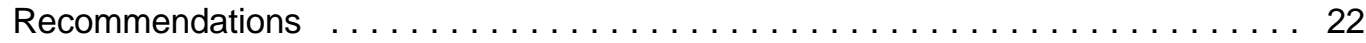

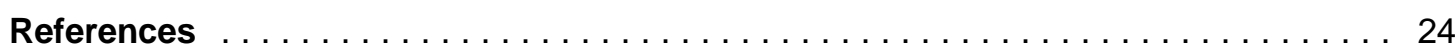

Distribution 


\section{List of Tables}

Tables

1 Coating systems and dry film thicknesses on hot-dip galvanized steel $\ldots \ldots 9$

2 Coating systems and dry film thicknesses on aluminum $\ldots \ldots \ldots \ldots \ldots$

3 Coating systems and dry film thicknesses on aluminum exposed for

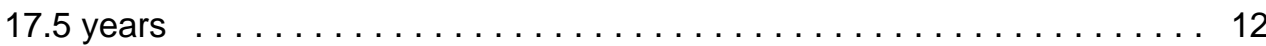

$4 \quad$ Coating adhesion on galvanized steel panels before and after exposure

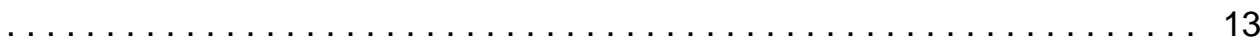

5 Results of $2016 \mathrm{~h}$ cyclic corrosion testing of coated galvanized steel

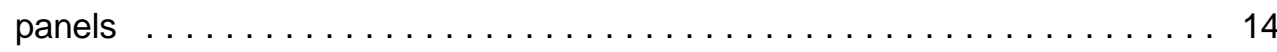

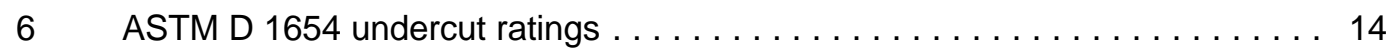

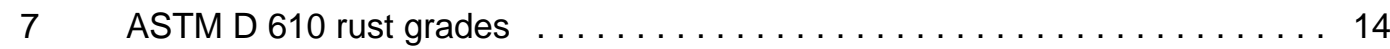

$8 \quad$ Coating adhesion on aluminum before and after exposure $\ldots \ldots \ldots \ldots \ldots$

9 Results of $2016 \mathrm{~h}$ cyclic corrosion testing of coated aluminum panels $\ldots \ldots 18$

10 Results of $120 \mathrm{~d}$ freshwater immersion tests on coated aluminum panels

11 Results of 17.5 year freshwater immersion tests on coated aluminum . . . . 19 


\section{Introduction}

\section{Background}

Both aluminum and galvanized steel are used on many Corps of Engineers projects. Typical uses indude miscellaneous architectural components such as hand rails, window frames, and piping. Other uses include machinery components and larger structural components such as bulkheads.

Aluminum is ordinarily quite stable in most environments and does not corrode beyond the formation of a thin protective layer of oxidation on the surface. However, in chemical, marine, industrial, and salt and fresh water immersion environments, al uminum may corrode at a significant rate. In these environments aluminum corrosion is usual ly local ized and characteristically it shows up as pitting of the metal. In such cases aluminum is usually painted for protection.

Hot-dip zinc galvanizing is a common method for protecting steel surfaces from corrosion. Zinc metal sacrifices itself to protect thesteel from corrosion, that is, the zinc corrodes instead of the steel substrate. In normal atmospheric exposures zinc galvanizing corrodes at a fairly slow rate. However, zinc is a fairly reactive metal and can corrodequite rapidly in low- or high-pH environments. When the galvanic zinc coating is exhausted the steel substrate is left unprotected and begins to corrode. For this reason, galvanic zinc coatings are usually painted when used in corrosive environments.

Aluminum and galvanized metal items also may be painted for aesthetic reasons - either to improve uniformity of appearance or to blend in with nearby architectural components. However, not all coatings are suitable for use on aluminum or zinc-dipped galvanized steel. Many coatings that adhere well to ferrous metals can adhere poorly to nonferrous metals. Hot-dipped zinc galvanizing can beparticularly difficult to paint. Coatings that contain drying oils, when used on zinc surfaces, can undergo a chemical reaction called saponification wherein the ol eoresinous binder in the paint is converted to a soap. It is not unusual to see a paint system delaminate from a galvanized surface. A field survey conducted by the U.S. Navy indicates that paint delamination from galvanized substrates is one of the most common paint failures at Navy facilities (Drisko 1995). 
Civil Works Guide Specification CWGS-09940, Painting: Hydraulic Structures (December 1995), describes several coating systems for use on nonferrous metal substrates. Vinyl paint systems employing V-766e as the first coat are used on aluminum in fresh water immersion. For aluminum and galvanized substrates in marine and industrial atmospheric exposures, and in interior areas subject to high humidity and condensation, TT-P-38E Paint, Aluminum (Ready-Mixed) and TT-E-489J Enamel, Alkyd, Gloss, Low VOC* Content are used as topcoats over SSPC Paint No. 27, Basic Zinc Chromate-Vinyl Butyral Wash Primer. For interior architectural surfaces such as ductwork, grilles, piping, and conduit, SSPC Paint No. 27 and a topcoat to match surrounding surfaces is used. Galvanizing is not generally used for immersion applications.

Various government environmental regulations place limits on the VOC content of architectural and industrial maintenancecoatings. A national rulegoverning VOCs has been proposed by the U.S. Environmental Protection Agency (EPA) in response to the Clean Air Act Amendments of 1990. It is slated for implementation on 1 J anuary 1998. The upper limit for VOC content is anticipated to be $450 \mathrm{~g} / \mathrm{L}$ for industrial maintenance coatings, $250 \mathrm{~g} / \mathrm{L}$ for flat architectural coatings, and $350 \mathrm{~g} / \mathrm{L}$ for non-flat architectural coatings.

Another important issue also is raised by the Corps' continued use of SSPC Paint No. 27 (see CWGS-09940): this coating is pigmented with zinc chromate, a hexaval ent chromium compound known to cause cancer. At present zinc chromate is not banned by any Federal regulation. However, national trends in environmental protection and industrial hygiene make it advisable for the Corps to proactively investigate chromate-free alternative coatings that satisfy the performance specifications of SSPC Paint No. 27 and meet anticipated VOC content restrictions.

Federal acquisition reform will have an impact on what the Corps selects as alternative coatings. The revised Federal Acquisition Regulation, or FAR (60 FR 48231-48257) redefines the procurement process for Department of Defense agencies. Part 12 of the revised FAR states a clear preference for the procurement of commercial products and systems. Criteria documents (specifications) for procuring commercial products should not merely be directive, but should be based on performance data. In response to the revised FAR and other defense acquisition reforms, the Corps of Engineers has taken the initiative to eliminate the use of military-unique specifications from all future procurements.

* VOC: volatile organic compound. 
The U.S. Army Construction Engineering Research Laboratories (USACERL) was tasked to evaluate various off-the-shelf coating systems for (1) performance in protecting nonferrous metal surfaces and (2) compliance with antici pated VOC content restrictions and other industrial hygiene considerations.

\section{Objective}

The objective of this research was to evaluate the performance of selected coatings on aluminum and hot-dip galvanized steel substrates in various exposure environments to identify effective commercial or existing F ederal Specification paints that comply with applicable VOC restrictions.

\section{Approach}

Selected test and control coatings were evaluated in laboratory tests, including fresh water immersion and accelerated cyclic corrosion. Exposed test panels were evaluated for adhesion, blistering, delamination, undercutting at the scribe, and corrosion. Accelerated tests are the best available tool for assessing coatings performance in a practical time frame. Field exposures and fence tests, while more reliable, take too long to be practical. Accelerated test methods, correctly applied, can reliably predict the relative performance of coatings. Details of the test methodologies and procedures are discussed in Chapter 2, "Testing Procedures."

\section{Scope}

Although there is no current Federal requirement to eliminate chromate-based pigments from coatings used on nonferrous metal surfaces, chromates pose potential safety hazards to painting personnel. Therefore, some coating systems that contain no chromates were included in this study to provide the Corps with chromate-free alternatives to currently specified coatings.

\section{Mode of Technology Transfer}

It is recommended that the results of this research be incorporated into an update of CWGS-09940, Painting: Hydraulic Structures. 


\section{Units of Weight and Measure}

U.S. standard units of measureare used throughout this report. Conversion factors for Standard International units are provided in the table below.

$$
\begin{aligned}
1 \mathrm{in.} & =25.4 \mathrm{~mm} \\
1 \mathrm{oz} & =28.349 \mathrm{~g} \\
1 \mathrm{ft} & =0.305 \mathrm{~m} \\
1 \mathrm{sq} \mathrm{ft} & =0.093 \mathrm{~m}^{2}
\end{aligned}
$$




\section{Testing Procedures}

\section{Selection of Test Coatings}

Tables 1 and 2 list the coating systems tested in conjunction with hot-dip galvanized steel and al umi num substrates, respectively. Paint systems G1, G2, G3,

Table 1. Coating systems and dry film thicknesses on hot-dip galvanized steel.

\begin{tabular}{|l|l|l|l|c|}
\hline System & \multicolumn{1}{|c|}{ First Coat } & Second Coat & \multicolumn{1}{|c|}{ Third Coat } & $\begin{array}{c}\text { Film Thickness } \\
\text { (mils) }\end{array}$ \\
\hline G1 & SSPC Paint No. 27 & TT-P-19 & TT-P-19 & 4.6 \\
\hline G2 & SSPC Paint No. 27 & TT-P-38 & TT-P-38 & 5.0 \\
\hline G3 & SSPC Paint No. 27 & TT-E-489 & TT-E-489 & 4.5 \\
\hline G4 & SSPC Paint No. 27 & MIL-P-24441 & & 3.4 \\
\hline G5 & TT-P-19 & TT-P-19 & & 4.6 \\
\hline G6 & TT-E-2784 & TT-E-2784 & & 3.6 \\
\hline G7 & MIL-P-24441 & MIL-P-24441 & & 3.9 \\
\hline G8 & Carbomastic 90 Aluminum* & & & 5.7 \\
\hline G9 & Epoxy Mastic Aluminum II & & & 5.6 \\
\hline
\end{tabular}

* Carbomastic 90 Aluminum is manufactured by Carboline

** Epoxy Mastic Aluminum II is manufactured by Sherwin-Williams

Table 2. Coating systems and dry film thicknesses on aluminum.

\begin{tabular}{|l|l|l|l|c|}
\hline System & \multicolumn{1}{|c|}{ First Coat } & Second Coat & \multicolumn{1}{|c|}{ Third Coat } & $\begin{array}{c}\text { Film Thickness } \\
\text { (mils) }\end{array}$ \\
\hline A1 & SSPC Paint No. 27 & TT-P-19 & TT-P-19 & 4.4 \\
\hline A2 & SSPC Paint No. 27 & TT-P-38 & TT-P-38 & 2.7 \\
\hline A3 & SSPC Paint No. 27 & TT-E-489 & TT-E-489 & 4.0 \\
\hline A4 & TT-P-19 & TT-P-19 & & 4.5 \\
\hline A5 & TT-E-2784 & TT-E-2784 & & 3.0 \\
\hline A6 & MIL-P-24441 & MIL-P-24441 & & 4.3 \\
\hline A7 & Carbomastic 90 Aluminum & & & 6.9 \\
\hline A8 & Epoxy Mastic Aluminum II & & & 4.7 \\
\hline A9 & V-766e & V-766e & V-102e & 5.7 \\
\hline
\end{tabular}


and G4 are currently used by the Corps for painting gal vanized steel. E ach of these systems uses a wash primer substrate pretreatment to promote adhesion of the topcoat. System G1 uses an exterior gradeflat acrylic latex topcoat and is generally used for aesthetic purposes rather than to protect the galvanizing. System G2 employs an aluminum-pigmented tung oil-phenolic topcoat, and system G3 uses a gloss alkyd topcoat. These systems generally are used on atmospherically exposed galvanizing but also may be used on interior surfaces subject to high humidity and condensation. They afford a moderate amount of protection. System G4, which employs an epoxy-polyamide topcoat, is used for the same applications as systems G2 and G3, but it is generally considered more durable. Although galvanized steel generally is not recommended for immersion, system $\mathrm{G} 4$ is the best of the standard systems for this end use. Paint systems G5 and G7 are analogous to systems G1 and G4 only they do not use the wash primer pretreatment. System G6 is similar to $G 5$ except that it employs a semigloss acrylic as opposed to a flat acrylic coating. Systems G8 and G9 are aluminum-pigmented epoxy mastic coatings. These coatings comply with the performance requirements of a draft Commercial Item Description (CID) developed by USACERL and scheduled for publication by the General Services Administration (GSA) in 1997. Systems G8 and G9 were selected based on the expectation that their performance and potential end uses would be similar to that for system G7.

Paint systems $\mathrm{A} 1, \mathrm{~A} 2$, and $\mathrm{A} 3$ are currently used by the Corps for painting aluminum. Each of thesesystems uses a wash primer substrate pretreatment to promote adhesion of the topcoat. System Al uses an exterior grade flat acrylic latex topcoat and generally is used for aesthetic purposes rather than to protect the aluminum substrate. System A2 employs an al uminum-pigmented tung oil-phenolic topcoat and system A3 uses a gloss alkyd topcoat. These systems are generally used on atmospherically exposed aluminum but may also be used on interior surfaces subject to high humidity and condensation. They afford a moderate amount of protection. System A4 is analogous to system A1 only without the wash primer. System A5 is similar to A4 except that it employs a semigloss acrylic as opposed to a flat acrylic coating. Systems A6 and A9, respectively, are the Corps standard immersion grade epoxy-polyamide and vinyl paint systems for use on aluminum surfaces. Systems A7 and A8 are aluminum pigmented epoxy mastic coatings. These coatings comply with the performance requirements of a draft CID devel oped by USACERL and scheduled for publication in 1997 by GSA. Their performance and potential end uses were anticipated to be similar to those for systems A6 and A9. 
Thereader should note that the coating systems designated here as $G 1, G 2, G 3, G 4$, A1, A2, and A3 are Corps standard systems specified in CWGS-09940 and were used as experimental controls in this study.

\section{Preparation of Test Specimens}

Test coatings were spray-applied to hot-dip galvanized ( 2 ounces per square foot) steel and 6061-T6 aluminum-alloy panels measuring $3.0 \times 9.0 \times 0.125$ inches. Before paint application the alumi num and galvanized test panels were solvent cleaned in accordance with SSPC SP-1. The aluminum test panels also were abrasive-blasted before painting using 80 grit garnet media at $65 \mathrm{psi}$. The dry film thickness of each coat of paint was measured and recorded using nondestructivedry film thickness gages in accordance with ASTM D 1186 and D 1400 respectively for galvanized and aluminum substrates. An eddy current gage was used on the aluminum specimens and a magnetic gage on the galvanized specimens. Before exposure, all test panels were scribed to the base metal with a milling machine. The scribes measured approximately $1 / 8$ inch wide by 2 inches long and were located parallel to the long axis and centered on the lower half of the coupons.

\section{Test Methods}

In recent years advancements have been made in the development of more reliable accelerated test methods. One method, ASTM D 5894 Standard Practice for Cyclic Corrosion/UV Exposure of Painted Metal (Alternating Exposures in a Fog/Dry Cabinet and a UV/Condensation Cabinet), reportedly produces coating failure modes similar to those observed in actual atmospheric weathering. This method produces improved rank correlations between exterior-exposed and laboratoryexposed test panels (Simpson, Ray, and Skerry 1991).

In this study, six test coupons of each coating system on aluminum and galvanized test panels were exposed in accordance with ASTM D 5894 for a total of 2016 hours. The coatings periodically were evaluated for blistering and undercutting at the scribe in accordance with ASTM D 714 and ASTM D 1654. Panels were rated at $168,336,672,1344$, and 2016 hours. The areas adjacent to the scribe were rated separately such that each test panel received two ratings, one for the scribe and one for the rest of the panel.

Six test panels each for coating systems $A 6, A 7, A 8$, and $A 9$ on aluminum substrates also were evaluated for corrosion resistance in fresh water immersion. These panels were immersed in tap water maintained at between $70^{\circ} \mathrm{F}$ and $80^{\circ} \mathrm{F}$ 
and aerated to prevent stagnation. The coated specimens were evaluated after 7, 60 , and 120 days for blistering, filiform corrosion, and undercutting at the scribe. The area adjacent to the scribe was rated separately such that each test panel received two ratings, one for the scribe and one for the rest of the panel. The results of the short-term fresh-water immersion tests were compared to data from a USACERL 17.5-year fresh-water exposure of systems similar to A6 and A9 on abrasive-blasted and smooth aluminum test panels. ${ }^{*}$ These systems are described in Table 3.

The adhesion of each coating system was evaluated in accordance with ASTM D 3359, Measuring Adhesi on by Tape Test (Method B). Pre-exposure adhesion was measured at five locations on one test panel for each coating system. Adhesion also was measured at one spot on each of the six exposed test panels of each coating system one day after completion of the final cycle of the cyclic corrosion and fresh water immersion tests.

Table 3. Coating systems and dry film thicknesses on aluminum exposed for $\mathbf{1 7 . 5}$ years.

\begin{tabular}{|c|l|c|}
\hline System Designation & \multicolumn{1}{|c|}{ Description } & Film Thickness (mils) \\
\hline 2561 & V-766e on blast cleaned aluminum & 5.0 \\
\hline 2562 & V-766e on smooth aluminum & 6.0 \\
\hline 2565 & MIL-P-24441 on blast cleaned aluminum & 8.2 \\
\hline 2566 & MIL-P-24441 on smooth aluminum & 8.9 \\
\hline
\end{tabular}

* This study comprises long-term exposure testing of coated aluminum coupons that has been underway in the USACERL Paint Laboratory for more than 17 years. These test coupons were used as reference specimens for this research project. 


\section{Test Results and Discussion}

\section{Performance of Coatings on Hot-Dip Galvanized Steel}

Table 4 shows the results of the adhesion tests for the coated galvanized steel panels before and after exposure to cyclic corrosion testing (ASTM D 5894). Table 5 summarizes the results of the cyclic corrosion testing of the coated galvanized steel panels. ASTM D 1654, Standard Test Method for Evaluation of Painted or Coated Specimens Subjected to CorrosiveE nvironments, provides integer values or rating numbers for undercutting based on the mean undercutting measured at the scribe. ASTM D 610, Standard Test Method for Evaluating Degree of Rusting on Painted Sted Surfaces, provides integer values or rust grades corresponding to various percentages of rusted surface area. For clarity, Tables 6 and 7 list the integer values and corresponding degree of degradation for rust undercutting and rusting respectively.

Table 4. Coating adhesion on galvanized steel panels before and after exposure.

\begin{tabular}{|c|c|c|}
\hline System & Initial Adhesion & Adhesion After Cyclic Corrosion \\
\hline G1 & $\begin{array}{l}2 \mathrm{~B}, 2 \mathrm{~B}, 0 \mathrm{~B}, 0 \mathrm{~B}, 0 \mathrm{~B} \\
\text { Average }=0.8 \mathrm{~B}\end{array}$ & $\begin{array}{l}\mathrm{OB}, \mathrm{OB}, \mathrm{OB}, \mathrm{OB}, \mathrm{OB}, \mathrm{CD} \\
\text { Average }=0 \mathrm{~B}\end{array}$ \\
\hline G2 & $\begin{array}{l}\mathrm{OB}, \mathrm{OB}, \mathrm{OB}, \mathrm{OB}, \mathrm{OB} \\
\text { Average }=0 \mathrm{~B}\end{array}$ & $\begin{array}{l}\mathrm{OB}, \mathrm{OB}, \mathrm{OB}, \mathrm{CD}, \mathrm{CD}, \mathrm{CD} \\
\text { Average }=0 \mathrm{~B}\end{array}$ \\
\hline G3 & $\begin{array}{l}3 \mathrm{~B}, 2 \mathrm{~B}, 2 \mathrm{~B}, 2 \mathrm{~B}, 2 \mathrm{~B} \\
\text { Average }=2.2 \mathrm{~B}\end{array}$ & $\begin{array}{l}C D, C D, C D, C D, C D, C D \\
\text { Average CD }\end{array}$ \\
\hline G4 & $\begin{array}{l}1 \mathrm{~B}, 0 \mathrm{~B}, 0 \mathrm{~B}, 0 \mathrm{~B}, 0 \mathrm{~B} \\
\text { Average }=0.2 \mathrm{~B}\end{array}$ & $\begin{array}{l}\mathrm{OB}, \mathrm{OB}, \mathrm{OB}, \mathrm{OB}, \mathrm{OB}, \mathrm{CD} \\
\text { Average }=0 \mathrm{~B}\end{array}$ \\
\hline G5 & $\begin{array}{l}\mathrm{OB}, \mathrm{OB}, \mathrm{OB}, \mathrm{OB}, \mathrm{OB} \\
\text { Average }=0 \mathrm{~B}\end{array}$ & $\begin{array}{l}\mathrm{OB}, \mathrm{OB}, \mathrm{OB}, \mathrm{OB}, \mathrm{CD}, \mathrm{CD} \\
\text { Average }=0 \mathrm{OB}\end{array}$ \\
\hline G6 & $\begin{array}{l}3 \mathrm{~B}, 3 \mathrm{~B}, 3 \mathrm{~B}, 2 \mathrm{~B}, 2 \mathrm{~B} \\
\text { Average }=2.6 \mathrm{~B}\end{array}$ & $\begin{array}{l}\mathrm{OB}, \mathrm{OB}, \mathrm{OB}, \mathrm{OB}, \mathrm{CD}, \mathrm{CD} \\
\text { Average }=0 \mathrm{OB}\end{array}$ \\
\hline G7 & $\begin{array}{l}2 \mathrm{~B}, 2 \mathrm{~B}, 2 \mathrm{~B}, 1 \mathrm{~B}, 1 \mathrm{~B} \\
\text { Average }=1.6 \mathrm{~B}\end{array}$ & $\begin{array}{l}\mathrm{OB}, \mathrm{OB}, \mathrm{OB}, \mathrm{OB}, \mathrm{CD}, \mathrm{CD} \\
\text { Average }=0 \mathrm{~B}\end{array}$ \\
\hline G8 & $\begin{array}{l}2 \mathrm{~B}, 2 \mathrm{~B}, 0 \mathrm{~B}, 0 \mathrm{~B}, 0 \mathrm{~B} \\
\text { Average }=0.8 \mathrm{~B}\end{array}$ & $\begin{array}{l}\mathrm{OB}, \mathrm{OB}, \mathrm{OB}, \mathrm{OB}, \mathrm{CD}, \mathrm{CD} \\
\text { Average }=0 \mathrm{~B}\end{array}$ \\
\hline G9 & $\begin{array}{l}\mathrm{OB}, \mathrm{OB}, \mathrm{OB}, \mathrm{OB}, \mathrm{OB} \\
\text { Average }=0 \mathrm{~B}\end{array}$ & $\begin{array}{l}2 \mathrm{~B}, \mathrm{OB}, \mathrm{OB}, \mathrm{OB}, 0 \mathrm{~B}, 0 \mathrm{~B} \\
\text { Average }=0.33 \mathrm{~B}\end{array}$ \\
\hline
\end{tabular}


Table 5. Results of $2016 \mathrm{~h}$ cyclic corrosion testing of coated galvanized steel panels.

\begin{tabular}{|c|c|c|c|}
\hline System & Rust (ASTM D 610) & Blistering (ASTM D 714) & Undercut (ASTM D 1654) \\
\hline G1 & $\begin{array}{l}9,7,8,8,8, C^{*} \\
\text { Average }=8.0\end{array}$ & None & $\begin{array}{l}0,0,0,0,0, C D \\
\text { Average }=0\end{array}$ \\
\hline $\mathrm{G} 2$ & $\begin{array}{l}8,6, C D, C D, 9, C D \\
\text { Average }=7.67\end{array}$ & None & $\begin{array}{l}0,0, C D, C D, 0, C D \\
\text { Average }=0\end{array}$ \\
\hline G3 & all CD & & all $C D$ \\
\hline G4 & $\begin{array}{l}10,9,10,9,9, \mathrm{CD} \\
\text { Average }=9.4\end{array}$ & None & $\begin{array}{l}0,0,0,0,0, C D \\
\text { Average }=0\end{array}$ \\
\hline G5 & $\begin{array}{l}6,8,8,8,7,7 \\
\text { Average }=7.33\end{array}$ & None & $\begin{array}{l}0,0,0,0,0,0 \\
\text { Average }=0\end{array}$ \\
\hline G6 & $\begin{array}{l}C D, C D, 8,8,8,8 \\
\text { Average }=8.0\end{array}$ & None & $\begin{array}{l}C D, C D, 0,0,2,0 \\
\text { Average }=0.5\end{array}$ \\
\hline G7 & $\begin{array}{l}8,8, C D, C D, C D, 8 \\
\text { Average }=8.0\end{array}$ & None & $\begin{array}{l}0,0, C D, C D, C D, 4 \\
\text { Average }=0.75\end{array}$ \\
\hline G8 & $\begin{array}{l}C D, C D, C D, C D, 10,10 \\
\text { Average }=10\end{array}$ & None & $\begin{array}{l}C D, C D, C D, C D, 0,0 \\
\text { Average }=0\end{array}$ \\
\hline G9 & $\begin{array}{l}10,10,9,10,10,9 \\
\text { Average }=9.67\end{array}$ & None & $\begin{array}{l}0,0,0,0,0,0 \\
\text { Average }=0\end{array}$ \\
\hline
\end{tabular}

${ }^{*} \mathrm{CD}$ means that the coating delaminated from the test panel during testing.

The initial coating adhesion measured on the panels before exposure in the cyclic corrosion test were surprisingly poor. Although ASTM D 3359 does not classify adhesion, ratings of $\mathrm{OB}$ and $\mathrm{IB}$ are generally considered poor, ratings of $2 \mathrm{~B}$ and $3 \mathrm{~B}$ fair, and $4 \mathrm{~B}$ and $5 \mathrm{~B}$ good. Although some individual test panels had fair adhesion, only systems G3 and G6 could be rated overall as having fair initial adhesion. All of the other systems had poor initial adhesion to the galvanized substrate. Final

Table 6. ASTM D 1654 undercut ratings.

Table 7. ASTM D 610 rust grades.

\begin{tabular}{|l|c|}
\hline \multicolumn{1}{|c|}{$\begin{array}{c}\text { Mean Undercut } \\
\text { (mm) }\end{array}$} & Rating Number \\
\hline Zero & 10 \\
\hline Over 0 to 0.5 & 9 \\
\hline Over 0.5 to 1.0 & 8 \\
\hline Over 1.0 to 2.0 & 7 \\
\hline Over 2.0 to 3.0 & 6 \\
\hline Over 3.0 to 5.0 & 5 \\
\hline Over 5.0 to 7.0 & 4 \\
\hline Over 7.0 to 10.0 & 3 \\
\hline Over 10.0 to 13.0 & 2 \\
\hline Over 13.0 to 16.0 & 1 \\
\hline Over 16.0 & 0 \\
\hline
\end{tabular}

\begin{tabular}{|c|l|}
\hline $\begin{array}{c}\text { Rust } \\
\text { Grade }\end{array}$ & \multicolumn{1}{|c|}{ Description } \\
\hline 10 & less than $0.01 \%$ of surface rusted \\
\hline 9 & less than $0.03 \%$ of surface rusted \\
\hline 8 & less than $0.1 \%$ of surface rusted \\
\hline 7 & less than $0.3 \%$ of surface rusted \\
\hline 6 & less than $1 \%$ of surface rusted \\
\hline 5 & less than $3 \%$ of surface rusted \\
\hline 4 & less than $10 \%$ of surface rusted \\
\hline 3 & approximately one sixth of surface rusted \\
\hline 2 & approximately one third of surface rusted \\
\hline 1 & approximately one half of surface rusted \\
\hline 0 & approximately $100 \%$ of surface rusted \\
\hline
\end{tabular}


adhesion after exposure to cyclic weathering was even poorer overall. Theadhesion could not be measured on one-third of the exposed test panels because the coating had delaminated. There does not appear to be a correlation between initial adhesion and coating failure by delamination. For system $\mathrm{G} 6$ with the best initial adhesion, the coating delaminated from two of six test panels. For the system with the second best initial adhesion rating all of the test panels delaminated during cyclic corrosion testing. One of two paint systems with the poorest initial adhesion did not delaminate at all during cyclic corrosion testing. Both Drisko (1995) and Morcillo (1989) have observed that there is no apparent correlation between initial adhesion and long-term performance of coating systems on galvanized steel. Drisko measured theadhesion of 26 coating systems by a method si milar to ASTM D 4541, Standard Test Method for Pull-Off Strength of Coatings Using Portable Adhesion Testers. (Threewerethesameas evaluated in the current study.) Drisko measured average pull-off adhesions of 342, 276, and $402 \mathrm{~kg} / \mathrm{cm}^{2}$ for systems G1, G5, and G7, respectively. Comparing adhesion results by pull-off (Drisko) and tape tests for these three systems shows the same rank order (i.e., G7 > G1 > G5). Drisko measured coating adhesion on galvanizing applied by both the continuous and batch-dip processes. The continuous-dip process produces a somewhat smoother surface than the batch dip process. There was no discernible overall trend in terms of initial adhesion versus method of galvanizing. Only systems using the same waterborne epoxy primer appeared to have measurably better adhesion on the rougher batch-dipped galvanized steel.

Morcillo (1989) also measured adhesion of coatings to hot-dip galvanized steel. He concluded that generally poor adhesion of all coating systems occurs when applied to unweathered galvanized steel and that adhesion is better for coatings applied to galvanized surfaces weathered in mild, unpolluted atmospheres or surfaces lightly etched by abrasive blasting. However, a publication prepared by the American $\mathrm{H}$ ot Dip Galvanizers Association and the Zinc Institute (10M-3/86, 1986) recommends that galvanizing not be weathered before painting because of the many other variables involved. This publication recommends instead that sweep blasting should be performed before painting to decrease smoothness and improve paint adhesion. The test panels used in the current study were not weathered or blasted before applying the paint coatings. Better initial adhesion may have been possible if the panels had been blasted or weathered before coating. However, neither blasting nor weathering are recommended in CWGS-09940 and are not standard procedures within the Corps for preparing galvanized surfaces.

Nearly all of the panels exposed to cyclic corrosion testing showed undercutting or loss of coating adhesion at the scribe of more than $16 \mathrm{~mm}$ (rating $=0$ ). One-third of all test panels exhibited coating delamination during testing. All of the coating 
systems had poor adhesion at the completion of testing. Overall the performance of the coating systems was relatively poor. Differences in coating performance are relatively minor and it is difficult to distinguish between those that may be better or worse than others. Qualitatively, system G3 (wash primer and alkyd topcoat) had the worst performancebecausethecoating system del aminated from all six test panels. Conversely, system G9 (aluminum epoxy mastic) was the best becausenone of the test panels exhibited coating delamination. System G9 also had comparatively less surface rust than most of the other systems.

As a group, the standard Corps paint systems (G1, G2, G3, and G4) did not perform any better or worse than the alternative coatings evaluated in this study. The performance of systems G1 and G5 (TT-P-19 flat acrylic latex with and without wash primer) was not significantly different. The performance of systems $\mathrm{G} 4$ and G7 (MIL-P-24441 epoxy polyamide with and without wash primer) also was not noticeably different. The performance of the two latex systems (G5 and G6) was not discernibly different. E poxy system G9 appears to be superior to epoxies $\mathrm{G} 7$ and G8, and G7 appears marginally better than G8. G9 is an amido amine-cured epoxy coating and $\mathrm{G} 8$ is an amine-cured epoxy. E poxy-polyamides and amido amines are generally more resistant to alkaline environments than are amine-cured epoxies. This could be an important factor because zinc galvanizing reacts in moist environments to produce alkaline zinc salts. As a group the performance of the acrylic latex coatings $\mathrm{G} 5$ and $\mathrm{G} 6$ was not noticeably different from that of the epoxy coatings G7, G8, and G9. Publication 10M-3/86, prepared by the American Hot Dip Galvanizers Association and the Zinc Institute, recommends polyamide-cured but not polyamine-cured epoxy coatings for use on galvanized substrates. The same report also recommends latex acrylic coatings, as does Weismantel (1981).

Drisko's work compared the performance of 26 systems over a 4.5 year period at two marine atmospheric sites, one with acid rain and one without acid rain. Drisko rated test coatings based on under-film corrosion, chalking, debonding, and other indications of deterioration. At the site without acid rain, a latex system equal to system G5 had excellent performance and a second latex system similar to system G6 also showed excellent performance. Most of the epoxy coating systems in Drisko's study al so exhibited excel lent performance at the marine site without acid rain including a system equal to G7. Drisko also found that alkyd coatings performed well when used over a wash primer but failed when a wash primer was not used (Drisko 1995). 


\section{Failure Mechanisms of Coatings on Galvanized Steel}

A field survey of Navy facilities found that coating failures on galvanized steel substrates, particularly delamination of the entire paint system, were among the most common of all paint failures (Drisko). Morcillo also makes note of the commonplace occurrence of coating delamination failures on galvanized steel as does the report prepared by the American Hot Dip Galvanizers Association and the Zinc Institute. Suggested causes for delamination failures include saponification of drying oil resins, alkaline attack of other paint resins, extreme smoothness of surface, preservative oils, soluble salt contamination, and galvanizing flux contamination. Numerous methods have been suggested for overcoming premature adhesive failures. These include weathering of new galvanized substrates, sweep blasting, solvent cleaning, detergent cleaning, steam cleaning, hot and cold phosphate pretreatments, and pretreatment with wash primer.

The coating failures experienced during cyclic corrosion testing wereessentially the same as those observed in actual exposures, namely coating delamination and poor adhesion. To a certain extent the poor performance observed for the coatings evaluated in this study may be the result of the severity of the cydic corrosion test method. ASTM D 5894 includes extended periods of exposure at essentially 100\% relative humidity. Galvanized surfaces subjected to high humidity or constant wetness may form alkalinezinc corrosion products beneath the paint film that may interfere with or destroy the adhesion of the protective coating. ASTM D 5894 is a relatively new test method, and its use for evaluating the performance of coatings applied over surfaces other than steel has not yet been validated in practice. However, because the results observed during testing closely mimic the failure modes seen in the field it is likely that the test method does have merit. Certainly the method is a much faster and more economical means of screening the performance of protective coatings on galvanized steel than actual field exposure.

\section{Performance of Coatings on Aluminum}

Table 8 shows the results of the adhesion tests for the coated aluminum test panels before and after exposure to cyclic corrosion and immersion testing. Tables 9 and 10 summarize the overall results of the cyclic corrosion and immersion tests respectively. For purposes of comparison, Table 11 summarizes the results of longterm fresh-water immersion testing of paint systems very similar to A6 (epoxypolyamide) and A9 (vinyl). ASTM D 1654, Standard Test Method for Evaluation of Painted or Coated Specimens Subjected to CorrosiveE nvi ronments, provides integer 
Table 8. Coating adhesion on aluminum before and after exposure.

\begin{tabular}{|c|c|c|c|}
\hline System & Initial Adhesion & $\begin{array}{c}\text { Adhesion After Cyclic } \\
\text { Corrosion }\end{array}$ & Adhesion After Immersion \\
\hline $\mathrm{A} 1$ & $\begin{array}{l}2 \mathrm{~B}, 2 \mathrm{~B}, 2 \mathrm{~B}, 2 \mathrm{~B}, 2 \mathrm{~B} \\
\text { Average }=2.0 \mathrm{~B}\end{array}$ & $\begin{array}{l}4 \mathrm{~B}, 4 \mathrm{~B}, 4 \mathrm{~B}, 4 \mathrm{~B}, 4 \mathrm{~B}, 4 \mathrm{~B} \\
\text { Average }=4.0 \mathrm{~B}\end{array}$ & $\mathrm{~N} / \mathrm{A}$ \\
\hline $\mathrm{A} 2$ & $\begin{array}{l}\mathrm{OB}, \mathrm{OB}, \mathrm{OB}, \mathrm{OB}, \mathrm{OB} \\
\text { Average }=0 \mathrm{~B}^{*}\end{array}$ & $\begin{array}{l}5 \mathrm{~B}, 4 \mathrm{~B}, 4 \mathrm{~B}, 4 \mathrm{~B}, 4 \mathrm{~B}, 4 \mathrm{~B} \\
\text { Average }=4.17 \mathrm{~B}\end{array}$ & $\mathrm{~N} / \mathrm{A}$ \\
\hline A3 & $\begin{array}{l}3 \mathrm{~B}, 3 \mathrm{~B}, 2 \mathrm{~B}, 2 \mathrm{~B}, 2 \mathrm{~B} \\
\text { Average }=2.4 \mathrm{~B}\end{array}$ & $\begin{array}{l}3 \mathrm{~B}, 3 \mathrm{~B}, 3 \mathrm{~B}, 2 \mathrm{~B}, 2 \mathrm{~B}, 1 \mathrm{~B} \\
\text { Average }=2.33 \mathrm{~B}\end{array}$ & $\mathrm{~N} / \mathrm{A}$ \\
\hline A4 & $\begin{array}{l}3 \mathrm{~B}, 2 \mathrm{~B}, 2 \mathrm{~B}, 2 \mathrm{~B}, 1 \mathrm{~B} \\
\text { Average }=2.0 \mathrm{~B}\end{array}$ & $\begin{array}{l}4 \mathrm{~B}, 4 \mathrm{~B}, 4 \mathrm{~B}, 4 \mathrm{~B}, 3 \mathrm{~B}, 3 \mathrm{~B} \\
\text { Average }=3.67 \mathrm{~B}\end{array}$ & $\mathrm{~N} / \mathrm{A}$ \\
\hline A5 & $\begin{array}{l}5 \mathrm{~B}, 4 \mathrm{~B}, 4 \mathrm{~B}, 4 \mathrm{~B}, 4 \mathrm{~B} \\
\text { Average }=4.2 \mathrm{~B}\end{array}$ & $\begin{array}{l}5 \mathrm{~B}, 5 \mathrm{~B}, 5 \mathrm{~B}, 5 \mathrm{~B}, 4 \mathrm{~B}, 4 \mathrm{~B} \\
\text { Average }=4.67 \mathrm{~B}\end{array}$ & $\mathrm{~N} / \mathrm{A}$ \\
\hline A6 & $\begin{array}{l}3 \mathrm{~B}, 2 \mathrm{~B}, 2 \mathrm{~B}, 1 \mathrm{~B}, 1 \mathrm{~B} \\
\text { Average }=1.8 \mathrm{~B}\end{array}$ & $\begin{array}{l}4 \mathrm{~B}, 4 \mathrm{~B}, 3 \mathrm{~B}, 3 \mathrm{~B}, 3 \mathrm{~B} \\
\text { Average }=3.4 \mathrm{~B}\end{array}$ & $\begin{array}{l}2 B, 2 B, 2 B, 3 B, 3 B, 3 B \\
\text { Average }=2.5 B\end{array}$ \\
\hline A7 & $\begin{array}{l}5 \mathrm{~B}, 5 \mathrm{~B}, 4 \mathrm{~B}, 4 \mathrm{~B}, 4 \mathrm{~B} \\
\text { Average }=4.4 \mathrm{~B}\end{array}$ & $\begin{array}{l}4 \mathrm{~B}, 3 \mathrm{~B}, 3 \mathrm{~B}, 3 \mathrm{~B}, 3 \mathrm{~B}, 2 \mathrm{~B} \\
\text { Average }=3.0 \mathrm{~B}\end{array}$ & $\begin{array}{l}3 \mathrm{~B}, 3 \mathrm{~B}, 3 \mathrm{~B}, 4 \mathrm{~B}, 4 \mathrm{~B}, 4 \mathrm{~B} \\
\text { Average }=3.5 \mathrm{~B}\end{array}$ \\
\hline A8 & $\begin{array}{l}5 B, 5 B, 5 B, 5 B, 5 B \\
\text { Average }=5 B\end{array}$ & $\begin{array}{l}5 \mathrm{~B}, 5 \mathrm{~B}, 4 \mathrm{~B}, 4 \mathrm{~B}, 4 \mathrm{~B}, 4 \mathrm{~B} \\
\text { Average }=4.33 \mathrm{~B}\end{array}$ & $\begin{array}{l}4 \mathrm{~B}, 4 \mathrm{~B}, 4 \mathrm{~B}, 5 \mathrm{~B}, 5 \mathrm{~B}, 5 \mathrm{~B} \\
\text { Average }=4.5 \mathrm{~B}\end{array}$ \\
\hline A9 & $\begin{array}{l}5 \mathrm{~B}, 5 \mathrm{~B}, 5 \mathrm{~B}, 5 \mathrm{~B}, 4 \mathrm{~B} \\
\text { Average }=4.8 \mathrm{~B}\end{array}$ & $\begin{array}{l}5 B, 5 B, 5 B, 5 B, 5 B, 5 B \\
\text { Average }=5 B\end{array}$ & $\begin{array}{l}5 B, 5 B, 5 B, 5 B, 5 B, 5 B \\
\text { Average }=5 B\end{array}$ \\
\hline
\end{tabular}

${ }^{*}$ Failure was cohesive within topcoat or between coats.

Table 9. Results of $2016 \mathrm{~h}$ cyclic corrosion testing of coated aluminum panels.

\begin{tabular}{|c|c|c|c|}
\hline System & Blistering & Blistering at Scribe & Undercut \\
\hline $\mathrm{A} 1$ & $8 \mathrm{D}, 8 \mathrm{D}, 8 \mathrm{D}, 8 \mathrm{D}, 8 \mathrm{D}, 8 \mathrm{D}$ & $8 \mathrm{D}, 8 \mathrm{D}, 8 \mathrm{D}, 8 \mathrm{D}, 8 \mathrm{D}, 8 \mathrm{D}$ & $\begin{array}{l}10,10,9,9,10,9 \\
\text { Average }=9.5\end{array}$ \\
\hline $\mathrm{A} 2$ & $\begin{array}{l}10,10,10,10,10,10 \\
\text { (none) }\end{array}$ & $\begin{array}{l}10,10,10,10,10,10 \\
\text { (none) }\end{array}$ & $\begin{array}{l}10,10,10,10,9,10 \\
\text { Average }=9.83\end{array}$ \\
\hline A3 & $10,10,10,9 F, 10,10$ & $\begin{array}{l}10,10,10,10,10,10 \\
\text { (none) }\end{array}$ & $\begin{array}{l}9,9,9,9,9,9 \\
\text { Average }=9.0\end{array}$ \\
\hline A4 & $8 \mathrm{D}, 8 \mathrm{D}, 8 \mathrm{D}, 8 \mathrm{D}, 8 \mathrm{D}, 8 \mathrm{D}$ & $8 \mathrm{D}, 8 \mathrm{D}, 8 \mathrm{D}, 8 \mathrm{D}, 8 \mathrm{D}, 8 \mathrm{D}$ & $\begin{array}{l}10,10,10,10,10,10 \\
\text { Average }=10.0\end{array}$ \\
\hline A5 & $\begin{array}{l}10,10,10,10,10,10 \\
\text { (none) }\end{array}$ & $\begin{array}{l}10,10,10,10,10,10 \\
\text { (none) }\end{array}$ & $\begin{array}{l}10,10,7,10,9,10 \\
\text { Average }=9.33\end{array}$ \\
\hline A6 & $\begin{array}{l}10,10,10,10,10,10 \\
\text { (none) }\end{array}$ & $\begin{array}{l}10,10,10,10,10,10 \\
\text { (none) }\end{array}$ & $\begin{array}{l}10,10,10,9,810 \\
\text { Average }=9.5\end{array}$ \\
\hline A7 & $\begin{array}{l}10,10,10,10,10,10 \\
\text { (none) }\end{array}$ & $\begin{array}{l}10,10,10,10,10,10 \\
\text { (none) }\end{array}$ & $\begin{array}{l}10,10,10,10,9,10 \\
\text { Average }=9.83\end{array}$ \\
\hline A8 & $\begin{array}{l}10,10,10,10,10,10 \\
\text { (none) }\end{array}$ & $\begin{array}{l}10,10,10,10,10,10 \\
\text { (none) }\end{array}$ & $\begin{array}{l}10,10,10,10,10,10 \\
\text { Average }=10.0\end{array}$ \\
\hline A9 & $10,10,10,9 F, 10,10$ & $10,10,10,9 F, 10,10$ & $\begin{array}{l}9,10,9,10,9,9 \\
\text { Average }=9.33\end{array}$ \\
\hline
\end{tabular}


Table 10. Results of $120 \mathrm{~d}$ freshwater immersion tests on coated aluminum panels.

\begin{tabular}{|c|l|l|l|}
\hline System & \multicolumn{1}{|c|}{ Blistering } & \multicolumn{1}{|c|}{ Blistering at Scribe } & \multicolumn{1}{c|}{ Undercut } \\
\hline A6 & $\begin{array}{l}10,10,10,10,10,10 \\
\text { (none) }\end{array}$ & $6 \mathrm{~F}, 4 \mathrm{~F}, 6 \mathrm{~F}, 4 \mathrm{~F}, 6 \mathrm{~F}, 10$ & $\begin{array}{l}8,8,8,8,8,8 \\
\text { Average }=8.0\end{array}$ \\
\hline A7 & $\begin{array}{l}10,10,10,10,10,10 \\
\text { (none) }\end{array}$ & $10,10,10,10,10,6 \mathrm{~F}$ & $\begin{array}{l}9,9,9,9,8,9 \\
\text { Average }=8.83\end{array}$ \\
\hline A8 & $\begin{array}{l}10,10,10,10,10,10 \\
(\text { none })\end{array}$ & $10,8 \mathrm{~F}, 6 \mathrm{~F}, 6 \mathrm{~F}, 10,10$ & $\begin{array}{l}10,10,10,9,9,9 \\
\text { Average }=9.5\end{array}$ \\
\hline A9 & $\begin{array}{l}10,10,10,10,10,10 \\
\text { (none) }\end{array}$ & $6 \mathrm{~F}, 6 \mathrm{~F}, 10,6 \mathrm{~F}, 6 \mathrm{~F}, 6 \mathrm{~F}$ & $\begin{array}{l}10,9,9,8,8,8 \\
\text { Average }=8.67\end{array}$ \\
\hline
\end{tabular}

Table 11. Results of $\mathbf{1 7 . 5}$ year freshwater immersion tests on coated aluminum.

\begin{tabular}{|l|c|c|c|c|c|c|}
\hline Description & $\begin{array}{c}\text { Surface } \\
\text { Preparation }\end{array}$ & Blisters & Undercut & $\begin{array}{c}\text { Filiform } \\
\text { Corrosion }\end{array}$ & Adhesion & $\begin{array}{c}\text { Thickness } \\
\text { (mils) }\end{array}$ \\
\hline V-766e & blasted & none & 10 & none & $5 \mathrm{~B}$ & 5.0 \\
\hline V-766e & smooth & none & 10 & none & $5 \mathrm{~B}$ & 6.0 \\
\hline MIL-P-24441 & blasted & none & 9 & none & $5 \mathrm{~A}^{*}$ & 8.2 \\
\hline MIL-P-24441 & smooth & none & 7 & none & $5 \mathrm{~A}^{*}$ & 8.9 \\
\hline
\end{tabular}

* Method A of ASTM D 3359 was used because of the higher film thickness of these coatings.

values or rating numbers for undercutting based on the mean undercutting measured at the scribe (see Table 6). ASTM D 714, Standard Test Method for Evaluating Degree of Blistering of Paints, quantifies blistering by size using a numerical scale from 10 (none) to 0 (very large), and by frequency (dense, medium dense, medium, and few). For ease of use, ASTM D 714 is accompanied by a pictorial standard. Blistering was rated separately for the areas directly adjacent to the scribe and for the rest of the test panel.

Although ASTM D 3359 does not classify adhesion values, ratings of OB and $1 \mathrm{~B}$ are generally considered poor, ratings of $2 \mathrm{~B}$ and $3 \mathrm{~B}$ fair, and $4 \mathrm{~B}$ and $5 \mathrm{~B}$ good. The initial coating adhesion measured on the aluminum panels before exposure in the cyclic corrosion test ranged from poor to good. The poor initial adhesion of system A2 is not surprising. TT-P-38 is a tung oil modified phenolic coating that cures by air oxidation. This process is fairly slow and it may require several weeks for the system to reach a level of cure sufficient to provide the degree of cohesive strength needed to withstand the tensile forces applied during the tape pull-off test. Indeed the adhesive failure noted for this coating system was cohesive within the coating. The adhesion of system A2 was rated as good after exposure in the cyclic corrosion test indicating that the coating had completed the cure process to the extent necessary to prevent cohesive failure within the coating. Several of the other 
systems (A1, A4, A6) also showed significant improvements in adhesion as measured after cyclic corrosion testing. After cyclic corrosion testing adhesion ranged from fair to good. Overall, four systems had significantly improved adhesion, three remained substantially the same, and two had slightly reduced adhesive strengths. One of the Corps standard systems for painting aluminum, system A3, had the poorest adhesion at the completion of cyclic corrosion testing. The four systems tested for adhesion after 120 days of immersion in fresh water did not show significant changes. System A6 had the poorest and system A9 had the best adhesion after fresh water immersion.

Most of the paint systems on aluminum performed well in cyclic corrosion testing showing good resistance to undercutting and blistering. However, systems A1 and A4 both blistered severely during testing. Both systems employ TT-P-19, an exterior-grade flat acrylic latex coating. (Latex coatings are known to blister when subjected to wet conditions for extended periods, and as previously noted systems A1 and A4 are not considered suitable for normal exterior exposures or for interior applications under conditions of high humidity or condensation. The remainder of the systems either showed no blistering or only very slight levels of it. The remainder of the systems should provide good to excellent performance for both interior and exterior atmospheric exposures. System A5 should provide the best long-term performance in terms of appearance. The epoxy and vinyl systems are preferred for applications with frequent or prolonged periods of wetness.

All of the systems tested in immersion showed at least some blistering at the scribe, but none blistered anywhere else on the panels. Systems A6 and A9, the standard Corps systems, each blistered on five of six panels. The two aluminum-pigmented epoxy coatings, A7 and A8, had blisters at the scribe on one and three panels respectively. The differences in blistering are minor, and overall each of these coating systems performed adequately. All of the systems tested in immersion had slightly more undercutting at the scribe than they did in cyclic corrosion testing. Overall, undercutting was still quiteacceptablewith even theleast resistant system exhibiting only $1 \mathrm{~mm}$ or less of undercutting.

As noted in Chapter 2, paint system A6 and a system very similar to A9 have been exposed to fresh water immersion in the USACERL Paint Laboratory for 17.5 years. These systems were applied to both smooth and grit-blasted aluminum panels. Both systems arestill providing excel lent protection and show no blistering, filiform corrosion, or other surface defects. No differences in adhesion were noted between the blast-roughened and smooth substrates - both systems exhibit good adhesion when tested in accordance with ASTM D 3359. The vinyl system had 
essentially no undercutting. The epoxy system had only slight undercutting with the smooth panels showing slightly more undercutting than the blasted panels.

Comparing the performance of thestandard Corps paint systems in short-term (120 days) and long-term (17.5 years) immersion, the performance of the coatings in the longer tests appears to be better. Based on the excellent long-term performance of the standard systems and the comparable performance of the aluminum epoxy coatings and the standard systems in short-term tests, it seems reasonable to predict good to excel lent long-term performance for thealuminum-pigmented epoxy coatings in immersion.

There does not appear to be a correlation between initial adhesion and final adhesion for either cyclic corrosion or immersion testing. Neither initial or final adhesion appear to be good predictors for blistering, undercutting, or overall performance for either cyclic corrosion or immersion. 


\section{Conclusions and Recommendations}

\section{Conclusions}

The test protocols used in this study adequately reflect the failures seen in practice on nonferrous metal substrates. ASTM D 5894, Standard Practice for Cyclic Corrosion / UV Exposure of Painted Metal (Alternating Exposures in a Fog/ Dry Cabinet and a UV/Condensation Cabinet), is capable of rapidly simulating field-type coating delamination failures on galvanized steel surfaces. Short-term immersion testing of coatings gives similar results when compared to very long term exposures.

Some of the commercial products evaluated in this study will be suitable for various Corps applications while complying with the VOC requirement outlined in Chapter 1. Specifically, it is concluded that all of the coatings recommended below will meet the anticipated upper VOC-content limits of $450 \mathrm{~g} / \mathrm{L}$ for industrial maintenance coatings, $250 \mathrm{~g} / \mathrm{L}$ for flat architectural coatings, and $350 \mathrm{~g} / \mathrm{L}$ for non-flat architectural coatings.

The chromate-containing wash primer used in a number of the Corps-standard systems does not enhance coating performance. Therefore, thechromate-containing wash primer is not necessary for effective protection of aluminum and galvanized surfaces. The coatings recommended below do not contain chromates.

It is concluded that alternative coating systems are available that are VOC-compliant and consistent with the intent of the Federal Acquisition Regulation. The use of one Military Specification paint is eliminated, and no new governmentunique criteria documents are needed.

\section{Recommendations}

\section{Coatings for Galvanized Steel}

Systems G5, G6, G8, and G9 are recommended for use on interior gal vanized steel surfaces where the environment is normally dry. Systems G5 and G6 are 
VOC-compliant Federal Specification latex coatings; system G5 should be used where $a$ flat finish is desired and system $\mathrm{G} 6$ should be used where a semigloss or gl oss appearance is required. Systems G8 and G9 may be procured by means of a commercial item description entitled Aluminum Epoxy Mastic Coating System, scheduled for publication by GSA during 1997.

Systems G5, G6, G8, and G9 also are recommended for interior aluminum or galvanized surfaces subject to high humidity and condensation.

Systems G6, G8, and G9 are recommended for exterior galvanized surfaces.

\section{Coatings for Aluminum}

Systems A4, A5, A7, and A8 are recommended for interior al uminum surfaces that are normally dry.

Systems A5, A7, and A8 are recommended for exterior and interior aluminum substrates subject to high humidity and condensation, with $\mathrm{A} 7$ and $\mathrm{A} 8$ preferred for wetter or morecorrosive applications. System A5 should providethe best long-term retention of appearance characteristics such as gloss and color for exterior applications with significant sunlight. Systems A7 and A8 are recommended for aluminum surfaces that will be continuously or intermittently immersed in fresh water.

\section{Guide Specification Update}

It is recommended that the coating systems noted above should beincorporated into the next revision of Civil Works Guide Specification CWGS-09940, Painting: Hydraulic Structures. 


\section{References}

ASTM D 610, Standard Method for Evaluating Degre of Rusting on Painted Surfaces (1989).

ASTM D 714, Standard Test Method for Evaluating Degree of Blistering of Paints (1987).

ASTM D 1186, Standard Test Methods for Nondestructive Measurement of Dry Film Thickness of Nonmagnetic Coatings Applied to Ferrous Base(1993).

ASTM D 1400, Standard Test Method for Nondestructive Measurement of Dry Film Thickness of Nonconductive Coatings Applied to Nonferrous Metal Base (1994).

ASTM D 1654, Standard Method for Evaluation of Painted or Coated Specimens Subjected to Corrosive Environments (1992).

ASTM D 3359, Standard Test Methods for Measuring Adhesion by TapeTest (1995).

ASTM D 5894, Standard Practice for Cyclic Corrosion / UV Exposure of Painted Metal (Alternating Exposures in a Fog/ Dry Cabinet and a UV/ Condensation Cabinet) (1996).

Civil Works Guide Specification CWGS-09940, Painting: Hydraulic Structures (December 1995).

Drisko, R.W., "A Five-Year Study of Environmentally Acceptable Coatings for Galvanized Steel," J ournal of Protective Coatings and Linings (September 1995).

Federal Specification TT-E-489, Enamel, Alkyd, Gloss, Low VOC Content (1994).

Federal Specification TT-E-2784, Enamel (Acrylic-E mulsion, Exterior Gl oss and Semigloss) (1991).

Federal Specification TT-P-19, Paint, Latex (Acrylic-E mulsion, Exterior Wood and Masonry) (1985).

Federal Specification TT-P-38, Paint, Aluminum, Ready-Mixed (1985).

Military Specification MIL-P-24441, Paint, E poxy-Polyamide(199?).

Morcillo, M., J . L. Ruiz, and J . Simancas, "Painting of Weathered Hot-Dip Galvanized Structural Steel Work,"J ournal of Protective Coatings and Linings, (November 1989).

Painting Galvanized Structural Sted, Publication 10M-3/86 (Zinc Institute, Inc., New York, and American Hot Dip Galvanizers Association, Inc., Washington, DC, March 1986). 
Simpson, C.H., C.J . Ray, and B.S. Skerry, "Accelerated Corrosion Testing of I ndustrial Maintenance Paints using a Cyclic Corrosion Weathering M ethod,"J ournal of ProtectiveCoatings and Linings (May 1991).

SSPC Paint No. 27, Basic Zinc ChromateVinyl Butyral Wash Primer (1991).

SSPC SP-1, Solvent Cleaning (1982).

SSPC-SP-5, White Metal Blast Cleaning (1985 and 1991 editorial changes).

SSPC-VIS 1, Visual Standard for Abrasive Blast Cleaned Sted (1989).

Weismantel, G.E., Paint Handbook (McGraw-Hill, 1981). 


\section{USACERL DISTRIBUTION}

Chief of Engineers

ATTN: CEHEC-IM-LH (2)

ATTN: CEHEC-IM-LP (2)

ATTN: CECG

ATTN: CECC-P

ATTN: CECC-R

ATTN: CECW

ATTN: CECW-EE

ATTN: CECW-O

ATTN: CECW-P

ATTN: CECW-PR

ATTN: CEMP

ATTN: CEMP-E

ATTN: CEMP-C

ATTN: CEMP-M

ATTN: CEMP-R

ATTN: CERD-C

ATTN: CERD-ZA

ATTN: CERD-L

ATTN: CERD-M (2)

ACS(IM) 22060

ATTN: DAIM-FDP

US Army Engr District

ATTN: Library (42)

US Army Engr Division

ATTN: Library (8)

CEWES 39180

ATTN: Library

CECRL 03755

ATTN: Library

Naval Facilities Engr Command

ATTN: Naval Facil. Engr. Service Ctr 93043-4328

Nat'I Institute of Standards \& Tech

ATTN: Library 20899

Defense Tech Info Center 22060-6218

ATTN: DTIC-O (2)

Tennessee Valley Authority

Federal Highway Administration

U.S. Bureau of Reclamation

Brazos River Authority

Bureau of Mines

84

$9 / 97$

This publication was reproduced on recycled paper. 